\title{
Occurrence and Concentration of Heavy Metals in a Rural Spring in South-eastern Nigeria
}

\section{*ANYANWU, ED; ONYELE, OG}

\author{
Department of Zoology and Environmental Biology, Michael Okpara University of Agriculture, Umudike, Abia State, Nigeria.
} *Corresponding Author Email: ekadon@yahoo.com; Tel.: +2347036373209

\begin{abstract}
Water is essential for life on earth and its quality is important for health and economic development; seasons, anthropogenic influences and natural processes affect the chemical composition of water. Springs are natural outflow of water from an underground supply to the ground surface and the quality may be altered due to exposure to metallic elements. Some of these elements are essential for humans; they can be dangerous at relatively high exposure levels. The aim of this study was to assess the occurrence and concentrations of heavy metals in a rural spring and determine its suitability for human consumption. Eight (8) heavy metals ( $\mathrm{Mn}, \mathrm{Cu}, \mathrm{Pb}, \mathrm{Fe}, \mathrm{Zn}, \mathrm{Cd}, \mathrm{Cr}$ and $\mathrm{Ni}$ ) were assessed between January and June 2017 in 3 stations; using Atomic Absorption spectrometer (AAS) and compared with SON and WHO standards. $\mathrm{pH}$ and Electrical conductivity were also determined in association with the metals with hand-held meters. Manganese, chromium, lead, iron and cadmium exceeded acceptable limits in various percentages of the samples and could basically be attributed to geogenic source exacerbated by seasonal and anthropogenic influences. The values of lead, iron and cadmium were higher and pose serious health risk to the consumers of the spring water over time. Rural springs hitherto considered safe due to little or no anthropogenic influences have been found to be unsafe due to geogenic contamination. The spring is therefore not suitable for drinking but can used for other domestic purposes. Human health risk assessment is recommended for this spring.
\end{abstract}

\section{DOI: https://dx.doi.org/10.4314/jasem.v22i9.19}

Copyright: Copyright $@ 2018$ Anyanwu and Onyele. This is an open access article distributed under the Creative Commons Attribution License (CCL), which permits unrestricted use, distribution, and reproduction in any medium, provided the original work is properly cited.

Dates: Received: 30 April 2018; Revised: 23 July 2018; Accepted: 30September 2018

Keywords: spring, heavy metal, geogenic, anthropogenic

Water is essential for life on earth. Freshwater supply is less than $1 \%$ of the water available on earth and human existence mainly depends on it. Water quality is important for health and economic development, factors like seasons, anthropogenic influences and natural processes affect the chemical composition of water (Reagen and Bookins-Fisher, 1997). Drinking water is generally obtained from surface waters, such as lakes, rivers and streams, and groundwater, such as spring and well waters. A spring is a natural outflow of water from an underground supply to the ground surface (USDA, 2012). Generally springs occur where ground surface and the impermeable subsurface strata intersect with the groundwater table. The forcing of the spring to the surface can be the result of a confined aquifer in which the recharge area of the spring water table rests at a higher elevation than that of the outlet (Bell, 1998). The discharge of the spring water fluctuates seasonally and mainly depends on rainfall pattern in the recharge area and variation in the amount of rainwater that is able to infiltrate the ground (Nushe et al., 2017). Spring water is usually safe from contaminants (i.e. pathogens, chemicals, metals); since groundwater is naturally filtered as it flows through the soil (Simiyu et al., 2009). Hence, spring water is generally safe for human consumption (Hawley, 2003). Spring water quality may be altered due to exposure to metallic elements (Marcovecchio et al., 2007; Simiyu et al., 2009). The term "heavy metals", refers to any metallic element that has relatively high density and applies to the group of metals and metalloids with atomic density greater than $5 \mathrm{~g} / \mathrm{cm}^{3}$ (Oveset al., 2012). Although some elements are essential for humans, they can be dangerous at relatively high exposure levels (Domingo, 1994; Goorzadi et al., 2009). Heavy metal pollution of soil and water has become one of the main concerns of human beings recently (Namaghi et al., 2011) and is often associated with variables of concealment, persistency and irreversibility (Zhu et al., 2012). Heavy metals occur naturally in rocks, but most of the heavy metals occurrences originate from anthropogenic sources. Natural sources include geological strata rich in some elements which may contaminate aquifers. Heavy metals may contaminate the surface water, springs and groundwater resulting in deterioration of drinking water quality. The overdependence of both human and animal activities 
on these spring water sources thus makes them susceptible to pollution (Pigweh and Joseph, 2016). Previous study showed that the some drinking water parameters of Iyinna Spring exceeded standard limits (Anyanwu and Ihediwah, 2015); this study therefore is aimed at assessing the occurrence and concentrations of heavy metals in Iyinna spring and determine its suitability for human consumption.

\section{MATERIALS AND METHODS}

Description of Study area and sampling stations: Iyinna spring is located at Umuariaga Community in Ikwuano Local Government Area of Abia State, Southeast Nigeria. The Iyinna spring is located in a valley and surrounded by hills; originating from a rock and piped to an open area where the villagers can have access to it. Umuariaga Community is located on north-east of the state within a geographical location of $\mathrm{N} 5^{\circ} 28^{\prime} 00^{\prime \prime}$ to $\mathrm{N} 5^{\circ} 29^{\prime} 00^{\prime \prime}$ and E7 $32^{\prime} 30^{\prime \prime}$ to E7 34 '30", about a distance of 9-10 km from Umuahia, Abia State capital and less than 500 metres from the main gate of Michael Okpara University of Agriculture, Umudike, Nigeria (Fig. 1). The Iyinna spring has no nearby houses around but the villagers and farming community come there to fetch water for various domestic uses.

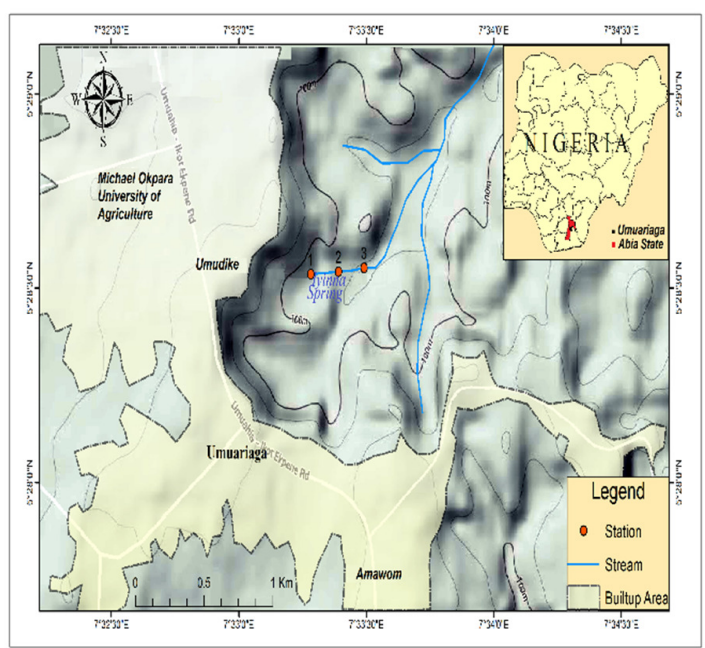

Fig. 1: Map of Umuariaga Community in Ikwuano Local Government Area of Abia State, Southeast Nigeria showing the sampling stations of Iyinna

The spring was divided into three stations for the purpose of this study. Station 1 is the source of the spring; the water is piped out to an open area from the rock. It is located in a valley which limits accessibility. This station is forested but has ferns (Diplzium sammatii) and three cornered leek (Allium triquetrum) growing around the edge of water. The substrate is made of sharp white sand; soap particles, wrappers and refuse were dumped around the edge of this station. Children do normally fetch drinking water in this station. Station 2 is about 290 metres downstream of Station 1 and located within a palm bush. A number of Kolanut (Kola nitida) plants grow around the edge of this station. The channel is narrower and the substrate is sharp brown sand and no human activities were observed during the period of the study. Station 3 is about 300 metres downstream of Station 2. The substrate is a combination of silt and sand and the edge of the water was cleared. Human activities are intense here because it is easily accessible. The farming community use the water for drinking, washing, bathing, and fermenting of cassava (Anyanwu and Ihediwah, 2015).

Samples collection and analyses: Water samples were collected from Iyinna Spring monthly from January to June 2017. The samples were collected with a 1 litre water sampler, transferred into a clean $250 \mathrm{ml}$ plastic bottle and acidified with Nitric acid $\left(\mathrm{HNO}_{3}\right)$ according to Sharma and Tyagi (2013). $\mathrm{pH}$ and electrical conductivity were determined insitu using Hanna Portable Meter (HI9811-5).The water samples were digested using concentrated Analar Nitric acid according to Zhang (2007). The UNICAM Solaar 969 atomic absorption spectrometer (AAS) which uses acetylene-air flame was used for the determination of Heavy Metals. All the results were statistically analysed using single factor ANOVA and Least Significant Difference (LSD) test was performed to determine the location of significant differences. Correlation analysis was also carried out to determine the relationships between $\mathrm{pH}$, conductivity and the heavy metals (0.05). Correlation is a method used to evaluate the degree of interrelation and association between two variables (Nair et al., 2005). A correlation of +1 indicates a perfect positive relationship between two variables. A correlation of -1 indicates that one variable changes inversely with relation to the other. A correlation of zero indicates that there is no relationship between the two variables (Kapil et al., 2009).

\section{RESULTS AND DISCUSSION}

The summary of the $\mathrm{pH}$, electrical conductivity and heavy metal contents are presented in Table 1. ANOVA showed no significant difference among the stations in all the parameters. The $\mathrm{pH}$ value recorded ranged between 4.72 and 6.11 . The lowest $\mathrm{pH}$ value was recorded in station 1 in February 2017 while the highest $\mathrm{pH}$ value was recorded in station 2 in March 2017. All the $\mathrm{pH}$ values recorded were outside the acceptable limits set by SON (2007) and WHO (2017) and was below the desirable limit in $100 \%$ of samples. $\mathrm{pH}$ correlated positively and significantly with 
Conductivity in stations 1 (0.803) and 2 (0.706) respectively. The $\mathrm{pH}$ values showed that the water is acidic; attributed to geogenic influence. This is in line with previous studies in the area (Igboekwe et al., 2011; Amos-Uhegbu et al., 2013; Chukwu and Nwachukwu, 2013; Igboekwe et al., 2013; Anyanwu and Ihediwah, 2015). These $\mathrm{pH}$ values are unacceptable for water meant for drinking according to World Health Organization (2017) and Nigerian Standard for Drinking Water Quality (SON, 2007) limits. Heavy metals are more soluble at low $\mathrm{pH}$ levels, thus they are more available and toxic. At low $\mathrm{pH}$ levels metal cations are released into the water body instead of being absorbed into the sediment (Radojevic and Bashkin, 1999).

\begin{tabular}{|c|c|c|c|c|c|}
\hline Parameter & $\begin{array}{l}\text { Station 1 } \\
\mathrm{X} \pm \text { S.E. }\end{array}$ & Station $2 \mathrm{X} \pm$ S.E. & $\begin{array}{l}\text { Station } 3 \\
\text { X } \pm \text { S.E } \\
\end{array}$ & $\begin{array}{l}\text { SON } \\
2007 * \\
\end{array}$ & $\begin{array}{l}\text { WHO } \\
2017 * *\end{array}$ \\
\hline$\overline{\mathrm{pH}}$ & $\begin{array}{l}5.19 \pm 0.19 \\
(4.72-5.94)\end{array}$ & $\begin{array}{l}5.40 \pm 0.17 \\
(4.90-6.11)\end{array}$ & $\begin{array}{l}5.49 \pm 0.14 \\
(5.11-5.94)\end{array}$ & $6.5-8.5$ & $6.5-8.5$ \\
\hline $\begin{array}{l}\text { Conductivity } \\
(\mu \mathrm{S} / \mathrm{cm})\end{array}$ & $\begin{array}{l}110.05 \pm 17.16 \\
(82.30-186.90)\end{array}$ & $\begin{array}{l}85.82 \pm 12.81 \\
(62.20-140.60)\end{array}$ & $\begin{array}{l}82.30 \pm 11.46 \\
(56.90-126.80)\end{array}$ & 1000 & 1000 \\
\hline $\mathrm{Mn}(\mathrm{Mg} / \mathrm{l})$ & $\begin{array}{l}0.13 \pm 0.01 \\
(0.08-0.17)\end{array}$ & $\begin{array}{l}0.10 \pm 0.02 \\
(0.06-0.16)\end{array}$ & $\begin{array}{l}0.22 \pm 0.07 \\
(0.07-0.51)\end{array}$ & 0.2 & 0.2 \\
\hline $\mathrm{Cu}(\mathrm{Mg} / \mathrm{l})$ & $\begin{array}{l}0.03 \pm 0.005 \\
(0.02-0.05)\end{array}$ & $\begin{array}{l}0.04 \pm 0.01 \\
(0.02-0.7)\end{array}$ & $\begin{array}{l}0.07 \pm 0.02 \\
(0.01-0.15)\end{array}$ & 3.0 & 3.0 \\
\hline $\mathrm{Pb}(\mathrm{Mg} / \mathrm{l})$ & $\begin{array}{l}0.04 \pm 0.01 \\
(0.02-0.07)\end{array}$ & $\begin{array}{l}0.04 \pm 0.01 \\
(0.03-0.07)\end{array}$ & $\begin{array}{l}0.17 \pm 0.11 \\
(0.01-0.72)\end{array}$ & 1.0 & 2.0 \\
\hline $\mathrm{Fe}(\mathrm{Mg} / \mathrm{l})$ & $\begin{array}{l}2.68 \pm 0.53 \\
(1.55-5.12)\end{array}$ & $\begin{array}{l}2.74 \pm 0.42 \\
(1.48-4.35)\end{array}$ & $\begin{array}{l}2.72 \pm 0.59 \\
(1.2-5.10)\end{array}$ & 0.003 & 0.003 \\
\hline $\mathrm{Zn}(\mathrm{Mg} / \mathrm{l})$ & $\begin{array}{l}0.59 \pm 0.09 \\
(0.21-0.84)\end{array}$ & $\begin{array}{l}0.54 \pm 0.05 \\
(0.33-0.64)\end{array}$ & $\begin{array}{l}0.61 \pm 0.11 \\
(0.29-0.90)\end{array}$ & 0.05 & 0.05 \\
\hline $\mathrm{Cd}(\mathrm{Mg} / \mathrm{l})$ & $\begin{array}{l}0.04 \pm 0.01 \\
(0.01-0.08)\end{array}$ & $\begin{array}{l}0.03 \pm 0.005 \\
(0.02-0.005)\end{array}$ & $\begin{array}{l}0.14 \pm 0.07 \\
(0.01-0.43)\end{array}$ & 0.01 & 0.01 \\
\hline $\mathrm{Cr}(\mathrm{Mg} / \mathrm{l})$ & $\begin{array}{l}0.03 \pm 0.005 \\
(0.02-0.05)\end{array}$ & $\begin{array}{l}0.03 \pm 0.005 \\
(0.02-0.05)\end{array}$ & $\begin{array}{l}0.09 \pm 0.04 \\
(0.01-0.24)\end{array}$ & 0.02 & 0.07 \\
\hline $\mathrm{Ni}(\mathrm{Mg} / \mathrm{l})$ & $\begin{array}{l}0.01 \pm 0.003 \\
(0.006-0.025) \\
\end{array}$ & $\begin{array}{l}0.01 \pm 0.002 \\
(0.008-0.021) \\
\end{array}$ & $\begin{array}{l}0.01 \pm 0.003 \\
(0.005-0.25) \\
\end{array}$ & 0.02 & 0.02 \\
\hline
\end{tabular}

* Nigerian Standard for Drinking Water Quality (NSDWQ); ** Guidelines for Drinking Water Quality (Fourth Edition) incorporating the first addendum

The electrical conductivity (EC) values ranged between 56.90 and $186.90 \mu \mathrm{S} / \mathrm{cm}$. The lowest conductivity value was recorded in station 2 in May 2017 while the highest conductivity value was recorded in station 1 in March 2017.The electrical conductivity values were within the acceptable limit for portable drinking water and within the range recorded by Anyanwu and Ihediwah (2015). Conductivity correlated positively and significantly with $\mathrm{Mn}$ (0.898), $\mathrm{Pb}$ (0.814), and $\mathrm{Fe}(0.732)$ in station 2 , and $\mathrm{Fe}(0.912)$ in station 3; showing that it is influenced by the presence of these metals. Liu et al (2017) observed that such relationship may be derived from the same sources or may be influenced by the same factor or factors. The Manganese values ranged between 0.06 and $0.51 \mathrm{mg} / \mathrm{l}$. The lowest value was recorded in station 2 in January 2017 while the highest value was recorded in station3 in February 2017. The values recorded in January and February 2017 exceeded the acceptable limit which was recorded in $11.1 \%$ of the samples. Manganese correlated positively and significantly with $\mathrm{Cu}(0.706)$ and $\mathrm{Cr}$ (0.768) in station $1, \mathrm{~Pb}(0.902)$ and $\mathrm{Fe}(0.893)$ in station 2, $\mathrm{Cu}$ (0.879), $\mathrm{Pb}$ (0.897), Zn (0.733), Cd (0.983), $\mathrm{Cr}$ (0.976) and $\mathrm{Ni}(0.934)$ in station 3. Manganese occurs naturally in both surface and groundwaters, as a result of weathered and solubilized manganese from soil and bedrock. This could be attributed to seasonal and anthropogenic influences because of increased use of the spring during the peak of dry season. Ljung and Vahte (2007) reported that elevated concentrations of manganese in drinking water are quite common in most countries. Extreme dose of manganese could lead to manganism (Dieter et al., 2005). Some recent studies have reported associations between levels of manganese in drinking water and cognitive behavioural problems in children (Bouchard et al., 2007). Excess manganese interferes with the absorption of dietary iron. Long-term exposure to excess levels may result in iron-deficiency anaemia. Increased manganese intake impairs the activity of copper metallo-enzymes. Symptoms of toxicity mimic those of Parkinson's disease (tremors, stiff muscles) and excessive manganese intake can cause hypertension in patients older than 40 (Blaurock-Busch, nd).

The copper values ranged between 0.02 and $0.15 \mathrm{mg} / \mathrm{l}$. The lowest values of copper values were recorded in May and June 2017 in stations 1 and 2 respectively. The highest value of copper was recorded in station 3 in February 2017. Copper correlated positively and 
significantly with $\mathrm{Pb}$ (0.814), Zn (0.799), Cd (0.710), $\mathrm{Cr}(0.828)$ in station $1, \mathrm{~Pb}(0.817), \mathrm{Zn}((0.956), \mathrm{Cd}$ (0.908), Cr (0.930) and Ni (0.900)in station 3. Copper values were within acceptable limits though higher values were recorded in station 3 , which could be attributed to anthropogenic and seasonal influences.

Lead, on the hand, ranged between 0.01 and $0.72 \mathrm{mg} / \mathrm{l}$. The lowest values were recorded in January and May 2017 in station 3 while the highest value was recorded in station 3 in February 2017 and could be attributed to geogenic source exacerbated by anthropogenic influences while lower levels recorded in May and June 2017 could be attributed to dilution arising from increased rainfall. The values recorded exceeded acceptable limits in $100 \%$ of the samples. Lead correlated positively and significantly with $\mathrm{Cd}(0.974)$, $\mathrm{Cr}(0.941), \mathrm{Ni}(0.745)$ in station $1, \mathrm{Fe}(0.957), \mathrm{Ni}$ (0.806) in station 2 and $\mathrm{Cd}(0.865), \mathrm{Cr}(0.871), \mathrm{Ni}$ (0.810) in station 3. High concentration of lead can affect the central nervous, renal, hematopoietic, cardiovascular, gastrointestinal, musculoskeletal, endocrine, reproductive, neurological, developmental and immunological systems (ATSDR, 2015).

The iron values ranged between 1.12 and $5.10 \mathrm{mg} / \mathrm{l}$. The lowest values were recorded in May 2017 in station 3 while the highest value was recorded in station 1 in April 2017. Iron correlated positively and significantly with Zn (0.799), Ni (0.866) in station 1, and $\mathrm{Ni}(0.822)$ in station 2 . The recorded values of iron exceeded acceptable limit by $100 \%$ of the samples and could be attributed to geogenic influence. Studies have shown that some shallow groundwater has naturally high iron content (Etu-Efeotor, 1981; Ophori, 2006). The trend is similar in the three stations with lower values recorded in May and June 2017 due to dilution. In high concentration, iron may produce neurological effects (Zheng et al., 2003). Long-term iron toxicity may involve iron-mediated oxidative damage to the mitochondrial genome leading to progressive dysfunction (De Freitas and Meneghini, 2001).

The zinc values ranged between 0.21 and $0.90 \mathrm{mg} / \mathrm{l}$. The lowest value was recorded in station 1 in June 2017 while the highest value was recorded in station 3 in February2017. Zinc correlated positively and significantly with $\mathrm{Cd}(0.808), \mathrm{Cr}(0.830)$ and (0.772) in station 3. All the zinc values recorded were well below acceptable limits. Station 3 had higher values between January and March 2017 and there was a general decrease in all the stations between April and June 2017, which could be attributed to dilution. The cadmium values ranged between 0.01 and $0.43 \mathrm{mg} / \mathrm{l}$. The lowest values were recorded in station 1 in May and June 2017. The highest value was recorded in station 3 in February 2017. Cadmium correlated positively and significantly with $\mathrm{Cr}(0.854)$, $\mathrm{Ni}(0.851)$ in station $1, \mathrm{Ni}(0.808)$ in station 2 and $\mathrm{Cr}$ (0.998), Ni (0.898) in station 3. Some of the cadmium values exceeded acceptable limits especially in station 3 between January and April 2017; recorded in 61.1\% of the samples. This could be attributed to geogenic source exacerbated by seasonal and anthropogenic influences. At high concentrations, cadmium affects the liver, placenta, kidneys, lungs, brain, and bones. Experimental data in humans and animals showed that cadmium may cause cancer in humans (Jarup et al., 2000; Nordberg et al., 2002).

The chromium values ranged between 0.01 and $0.24 \mathrm{mg} / \mathrm{l}$. The lowest value was recorded in station 3 in June 2017. The highest values were recorded in station 3 in February and in station 1 in June 2017. Chromium correlated positively and significantly with $\mathrm{Ni}(0.808)$ in station 2 and $\mathrm{Ni}(0.902)$ in station 3. Chromium had some values that exceeded acceptable limits especially in station 3 between January and March 2017; recorded in $11.1 \%$ of the samples. This could also be attributed to seasonal and anthropogenic influences. There was a general decrease between April and June 2017 attributable to dilution during the wet season. High concentrations of chromium may cause liver and kidney toxicity and genotoxic carcinogen (Strachan, 2010).

The nickel values ranged between 0.005 and $0.25 \mathrm{mg} / \mathrm{l}$. The lowest value was recorded in station 3 in May, 2017 and the highest value was also recorded in station 3 in February, 2017. All the values recorded were below acceptable limits though higher values were recorded in station 3 in January and February 2017, which could be attributed to seasonal and anthropogenic influences.

Conclusion: Manganese, chromium, lead, iron and cadmium exceeded acceptable limits in various percentages of the samples and could basically be attributed to geogenic source exacerbated by seasonal and anthropogenic influences. The values of lead, iron and cadmium were higher and pose serious health risk to the consumers of the spring water over time. Rural springs hitherto considered safe due to little or no anthropogenic influences have been found to be unsafe due to geogenic contamination. The spring is therefore not suitable for drinking but can used for other domestic purposes.

\section{REFERENCES}

ATSDR (2015). Toxicological Profiles, Toxic Substances Portal- Lead. Agency for Toxic Substances and Disease Registry. 
http://www.atsdr.cdc.gov/toxprofiles/tp.asp. Accessed 7th August 2017.

Amos-Uhegbu, C; Igbokwe, MU; Chukwu, GU (2013). Aquifer characterization and quality assessmentof groundwater in Umuahia-South areaof Abia State, Southern Nigeria. Pac. J. Sci. Technol.14(2):642-653.

Anyanwu, ED; Ihediwah, SU (2015). Drinking water quality of Iyinna spring, Umuriaga, Ikwuano Local Government Area, Abia State, Nigeria. J. Aquat. Sci. 30 (2): 317-328.

Bell, FG (1998). Environmental Geology: Principles and Practice. Wiley-Blackwell Science Ltd, New York.

Blaurock-Busch, E (nd). The clinical effects of Manganese

(Mn).http://www.tldp.com/issue/180/Clinical\%2 0Effects\%20of\%20Mn.html. Accessed $5^{\text {th }}$ May 2018.

Bouchard, M; Laforest, F; Vandelac, L; Bellinger, D; Mergler, D (2007). Hair manganese and hyperactive behaviours: pilot study of school-age children exposed through tap water. Environ. Health Perspect.115:122.

Chukwu, GU; Nwachukwu, E (2013). Groundwater quality assessment of some functional boreholes in Ikwuano from bacteriological and physicochemical studies. J. Environ. Sci. Wat. Res. 2(9):330- 335.

De Freitas, JM; Meneghini, R (2001). Iron and its sensitive balances in the cell. Mutation Res. 475 (1-2): 153.

Dieter, HH; Bayer, TA; Multhaulp, G (2005). Environmental copper and manganese in the pathophysiology of neurologic diseases (Alzheimer's disease and Manganism). Acta hydroch. Hydrob.33: 72-78.

Domingo, JL(1994).Metal-induced developmental toxicity in mammals: A review. J. Tox. Environ. Health 42:123-141.

Etu-Efeoter, JO (1981). Preliminary hydrogeochemical investigations of sub-surface waters in parts of the Niger Delta. Nig. J. Min. Geol.18:103-105.
Goorzadi, M; Vahabzadeh, G; Ghanbarpour, MR; Karbassi, AR (2009). Assessment of heavy metal pollution in Tilehbon river sediments, Iran. $J$. Appl. Sci. 9:1190-1193.

Hawley, RJ (2003). A Technical brief for spring box construction. Houghton: Michigan Technological University, Master's International Program, www.cee.mtu.edu/peacecorps.

Igboekwe, MU; Akankpo, OA; Udoinyang, IE (2011). Hydrochemical Evaluation of Groundwater Quality in Michael Okpara University of Agriculture, Umudike and Its Environs, Southeastern Nigeria. J. Wat. Res. Prot. 3:925929.

Igboekwe, MU; Eke, AB; Emeka-Chris, CC; Ihekweaba, G (2013).Geophysical Assessment and Groundwater Quality in Michael Okpara University of Agriculture, Umudike, Abia State. Pac. J. Sci. Technol. 14(2):565-575.

Jarup, L; Hellstrom, L; Alfven, T; Carlsson, MD; Grubb, A; Persson, B; Petersson, C; Spang, G; Schutz, A; Elinder, CG (2000). Low level exposure-cadmium and early kidney damage: the OSCAR Study. Occup. Environ. Med. 57: 668672.

Kapil, DM; Mamta, K; Sharma, DK (2009). Hydrochemical analysis of drinking water quality of Alwar District Rajasthan. Nat. Sci. 7(2):30-39.

Liu, Y; Yu, H; Sun, Y; Chen, J (2017). Novel assessment method of heavy metal pollution in surface water: A case study of Yangping River in Lingbao City, China. Environ. Eng. Res. 22(1): 31-39.

Ljung, K; Vahter, M (2007).Time to Re-evaluate the Guideline Value for Manganese in Drinking Water? Environ. Health Perspect. 115(11):1533 1538 .

Marcovecchio, JE; Botte, SE; Freije, RH (2007). Heavy metals, major metals, trace elements. In: Nollet, LMI; De Gelder, LSP (eds). Handbook of Water Analysis, 2nd edn (Food Science and Technology). CRC Press, Boca Raton, Florida, USA. 784pp.

Nair, GA; Mohamed, AI; Premkumar, K(2005). Physico-chemical parameters and correlation 
coefficients of ground waters of North-East Libya. Pollut. Res. 24(1):1-6.

Namaghi, HH; Karami, GH; Saadat, SA (2011).Study on chemical properties of groundwater and soil in ophiolitic rocks in Firuzabad, east of Shahrod, Iran: with emphasis to heavy metal contamination. Environ. Monit. Assess. 174: 57383.

Nordberg, G; Jin, T; Bernard, A; Fierens, S; Buchet, JP; Ye, T; Kong, Q; Wang, H (2002). Low bone density and renal dysfunction following environmental cadmium exposure in China. Ambio. 31:478-481.

Nushe, L; Milaim, S; Xhemë, L;Blerim, B; Mehush, A(2017). Assessment of Physico-Chemical Quality of Fresh Water Springs in Village Pepaj, Rugova Region, Kosova. J. Int. Environ. Application Sci. 12(1): 73-81.

Ophori, D (2006). Groundwater Quality in Shallow Domestic Water Wells, Ughelli, Nigeria. WebAddress:

http://www.iseg.giees.uncc.edu/abuja2006/Abstr acts/Abstract_ID_284

Oves, M; Khan, MS; Zaidi, A; Ahmad, E (2012). Soil contamination, nutritive value, and human health risk assessment of heavy metals: An overview. In: Zaidi, A;Wani, PA; Khan, MS(eds). Toxicity of heavy metals to legumes and bioremediation. Springer, Vienna. pp. 1-27.

Pigweh, IA; Joseph, IA (2016). Investigation of the Occurrence and Levels of Some Heavy Metals in Spring Water from Bazza, Pella and Yadim Areas of Adamawa State. Chem. Sci. Int. J. 17(4): XXXX.

Radojevic, M; Bashkin, VN (1999). Practical Environmental Analysis. Royal Society of Chemistry, Cambridge, UK.

Reagen, P; Bookins-Fisher, J (1997). Community health in the 21st century (First Edn).Pearson, London, UK.
Sharma, B; Tyagi, S (2013). Simplification of Metal Ion Analysis in Fresh Water Samples by Atomic Absorption Spectroscopy for Laboratory Students. J. Lab. Chem. Edu. 1(3):54-58.

Simiyu, GMN; Ngetich, J; Esipila, TA (2009). Assessment of spring water quality and quantity, and health implications in Tongaren division, Nozia River catchment, Kenya. Afr. J. Ecol. 47(s1):99-104.

SON (2007). Nigerian standard for drinking water quality. Nigerian Industrial Standard (NIS 554). Standards Organisation of Nigeria (SON), Abuja, Nigeria. pp. $14-17$

Strachan, S (2010). Heavy metal .Cur. Anaesth. Crit. Care 21:44-48.

USDA (2012). Chapter 12 - Springs and Wells," United States Department of Agriculture. Natural Resources Conservation Service. Part 650 National Engineering Handbook.210-VI-NEH, Amend. 60, July 2012. pp. 1 \& 5.

WHO (2017).Guidelines for drinking-water quality, $4^{\text {th }}$ edition, incorporating the $1^{\text {st }}$ addendum. World Health Organisation, Geneva. 631pp. Available at:

http://www.who.int/water_sanitation_health/publ ications/drinking-water-quality-guidelines-4including-1st-addendum/en/. Accessed $12^{\text {th }}$ January 2018.

Zhang, C (2007). Fundamental of Environmental Sampling and Analysis. Wiley, New York.

Zheng, W; Aschner, M; Ghers-Egea, JF (2003). Brain barrier systems: a new frontier in metal neurotoxicological research. Tox. Appl. Pharm. 192 (1):1-11

Zhu, X; Ji, H; Chen, Y; Qiao, M; Tang, L (2012). Assessment and sources of heavy metals in surface sediments of Miyun Reservoir, Beijing. Environ. Monit. Assess. 185:6049-6062. 